\title{
THE COMPARISON OF USING SNAKE LADDERS AND SCRABBLE MEDIA TOWARDS VOCABULARY MASTERY OF STUDENTS
}

\author{
Eka Pra Setiyawati \& Refai
}

Muhammadiyah Univeristy of Metro

\begin{abstract}
Vocabulary is an essential component in learning English. It influences four English skills; they are listening, speaking, reading, and writing, for getting a good result in English. In teaching learning process, the teacher often implements the less interesting method, technique, or even media of vocabulary mastery in teaching and learning process which make the students to be bored, inactive, an uniterested in memorizing English vocabulary. Some media can be interested as the solutions in vocabulary mastery, they are Snake Ladders media and Scrabble media.

The investigation was undergone by quantitative research. The researcher applied experimental research. This research underwent pre-test post-test control group design. To analyze data, $\mathbf{t}$-test formula is used to measure the result of collected data. From the $\mathbf{t}$-test measurement, it showed that t-test is 3.15 and t-table is 2.66 . It means that $\mathbf{t}$-hit $>\mathbf{t}$-table. Based on the collected data, there is different result of using Snake Ladders from Scrabble media toward students' vocabulary mastery. It was found that the students who are taught by using Snake Ladders resulted significant outcome than those are instructed by Scrabble media. It means that Snake Ladders is effective to improve the students' vocabulary mastery.
\end{abstract}

Key Words: Snake Ladders Media, Scrabble Media, Vocabulary Mastery.

The objective of this research is to find out which one is the most effective between Snake Ladders and Scrabble media to encourage students mastering English vocabulary in learning process in the class. The subjects of this research were the tenth grade students of MAN 1 Metro Batanghari Lampung Timur. There are three research variables applied in this research, they are a dependent variable, and two independent variables of the research. The dependent variable is vocabulary, whereas the independent variables are Snake Ladders and Scrabble media. As we know that vocabulary is one of the components in learning English which become the main basis of English skills. The learning English skills we means are listening, speaking, reading and writing skills. Penny (1991: 60) defines, "vocabulary is roughly, as the words we teach in the foreign language". Then, Barnhart (2008: 697) states that vocabulary as a stock of words used by person, class of people, profession, and a collection of list of words, usually in alphabetical order and defined. Relate to both statements, Hornby (1995: 1331) stated that vocabulary is the total number of words in a language, all the words known to a person or used in a particular book, a list of words with their meanings that accompanies a textbook in a foreign language. It can be concluded that vocabulary is a list of words and sometimes phrases, which usually arranged in alphabetical orders and defined; a dictionary, glossary, or lexicon. All the words are used by particular person, class, profession, etc.

According to Anonymous (2011) that Snake and Ladders is a game of luck played between any number of players over two in which the objective is to avoid the snake slides and climb the ladders to the end of the grid pattern playing board. Snake and Ladders actually is an old game which was believed to play by people in India from the second century of BC. In fact, snake ladders game has been 
experimented in foreign language learning especially in vocabulary learning. Yusuf and Aulia (2011) stated that snake ladders is an educative game. It can be the point of attention for the students. In order become an interesting and easy media for them, the researcher will modify some rules of the game for the purpose to make it simpler. There are only 20 spaces in the game board. First, the researcher provides the snake ladder board or wide paper, dice and glass. Second, the students should be in group of four, they are rendomized which one is the first player. Third, the first player who is in the start space has to shake the dice and throw it. Then it determines how many steps that will be ran by the player. Fourth, the player has to mention or pronounce the answers based on the command in the space in which he or she is staying along one minute. Finally, the player will continue her or his step if the answer is correct. Nevertheless, if the answer is wrong she or he has to step three spaces back. The winner is the player who can step the finish space fast. In this game, the students are encouraged not only to memorize English words as many as he/she can, but also enable $\mathrm{him} /$ her to pronounce the words correctly.

Based on Wikipedia Encyclopedia (2014) that Scrabble is a word game which is played by two to four players on a square board with a $15 \times 15$ grid of cells (individually known as "squares"), each of which accommodates a single letter tile. In official club and tournament games, play is between two players or, occasionally, between two teams each of which collaborates on a single rack. The board is marked with "premium" squares, which multiply the number of points awarded: eight dark red "triple-word" squares, 17 pink "double-word" squares, of which one, the center square (H8), is marked with a star or other symbol; 12 dark blue "triple-letter" squares, and 24 light blue "double-letter" squares. In 2008,
Hasbro changed the colors of the premium squares to orange for TW, red for DW, blue for DL, and green for TL. Despite this, the original premium square color scheme is still the preferred scheme for Scrabble boards used in tournaments.-The name of the game spelled out in game tiles from the English-language version. Each tile is marked with their point value, with a blank tile - the game's equivalent of a wild card-played as the word's first letter. The blank tile is worth zero points.

In an English-language set, the game contains 100 tiles, 98 of which are marked with a letter and a point value ranging from 1 to 10 . The number of points of each lettered tile is based on the letter's frequency in standard English writing; commonly used letters such as vowels are worth one point, while less common letters score higher, with $\mathrm{Q}$ and $\mathrm{Z}$ each worth 10 points. The game also has two blank tiles that are unmarked and carry no point value. The blank tiles can be used as substitutes for any letter; once laid on the board, however, the choice is fixed. Other language sets use different letter set distributions with different point values.

Tiles are usually made of wood or plastic and are 19 by 19 millimetres $(0.75 \mathrm{in} \times 0.75 \mathrm{in})$ square and $4 \mathrm{~mm}$ (0.16 in) thick, making them slightly smaller than the squares on the board. Only the rosewood tiles of the deluxe edition varies the width up to $2 \mathrm{~mm}$ ( $0.08 \mathrm{in})$ for different letters. Travelling versions of the game often have smaller tiles (e.g. $13 \mathrm{~mm} \times 13 \mathrm{~mm} \quad(0.51$ in $\times 0.51 \mathrm{in})$ ); sometimes they are magnetic to keep them in place. The capital letter is printed in black at the centre of the tile face and the letter's point value printed in a smaller font at the bottom right corner.

Related to the teacher's and the students' problem to motivate and encourage the students to improve their English vocabulary. The writers proposed 
their research by comparing two learning media (Snake Ladders and Scrabble) to find out which one is most effective media to encourage and motivate students to improving their English vocabulary.

As Gardner and Forman (cited in Collin and Griess, 2011) asserted that Snake Ladders is a board game which allow children to express themselves through all of their available expression, communicative and cognitive language. The snake ladders uses the board and a dice filled with 20 command boxes that must be conducted by the players. The command spaces have been modified to make the players (students) describe or mention some things, places, activities, and also inserting singing songs based on the various commands in the spaces.

Thiagarajan, S (1999) stated that Scrabble is an interesting game which is able to play by all family members and had been played almost around a century. Playing scrabble may persuade the players (students) to memorize indirectly the huge vocabulary actively and interestingly.

\section{Method}

The design of this study was true experimental research control group pretest and post-test design. It is aimed to determine the relationship between the independent variables and the dependent variable in a population.

Sugiono (2012: 60) stated that variable is something that formed something established by the researchers to study, in order to obtain information about it, then to take its conclusion. Based on the statement above that. In this study, there are three variables involved in this research. They are two independent variables; Snake Ladders and Scrabble, and a dependent variable; vocabulary mastery. In this case, the writers investigated the most effective media to instruct the students in learning English, especially to encourage them mastering English vocabulary.

The subject of this research is all the tenth grade students of MAN 1 Metro Batanghari Lampung Timur which consist of 286 male and famale students. Since the population is too big, the writers limited the number of population by appling the sampling technique recommended by the experts. The writers applied cluster random sampling to the population to determine which one would be an experimental and a control groups. The experimental group was instructed to use Snake Ladders in mastering vocabulary in the learning process, while the control group was taught by using Scrabble in earning their vocabulary in the learning process. This study was employed to find out the most effective media to master English vocabulary toward the students in the learning process.

To collect the research data, the writers applied paper and pencil vocabulary pre-test and post-test items to measure the students' vocabulary improvement. The paper and pencil based test items consisted of 30 items in multiple choice forms. The writers chose multiple choice items for the effectiveness in scoring system. To score 30 responses of the 30 questions of the test, the writers determined that the correct answer had score 1 per item, while the incorrect answer had score 0 per item. Thus, the total correct score would be multiplied by 100.

After producing the pre-and posttests multiple choice items, the writers measured the level of the instruments' validity and realibility. The writers determined the content validity measurement to figure out whether the instruments are valid or unvalid. As Gay (1990: 129) asserted that the degree to which a test measures an intended content area. Content validity is the extent of 
adequacy of the test instrument which would be applied to the research. The writers tested the instruments by taking a group of students out of the research samples to do the multiple choice items. Then, the result of the try out test was corrected and analyzed by the writers to see whether each item of the tests were eligible to apply in their research. To find out the level of realibility of the instrument, the writers applied split half items test of correlation product moment to measure the realibility of the instruments. After implementing the correlation product moment formula and analyzing the result of the calculation, the writers decided whether the test instruments are realiable or not. If they are realiable, the writer employed the test instruments to collecting the data, but if they are not realiable, the writers would mend the test intruments and started testing the validity or the realiability of the test intruments.

The next stage was the way the writers collected the data of the research. There were two kinds of collected data that the writers got from their research. They were, primary and secondary data. the primary data were the data which yielded by undertaking pre-and post-test to both of the research samples. Whereas, the secondary data were the data which outcome by observing and interviewing two groups students toward the implementation of both media in their learning process.

To analyze the resulted data, the writers employed the normality test, and the homogeneity test formulas, and measuring the hypothesis of the study. The normality test is operated to know whether the data distribution is in normal or in abnormal conditions. While, the homogeneity test formula is objected to determine the data variety. Whereas, the hypothesis test is undergone to determine whether the proposed hyphotesis were questions above were proved or not proved then to determine which one is the most valuable media to instruct students in learning and mastering English vocabulary effectively.

\section{Findings}

Based on the result of the validity test instruments, after the writers analyzed the instruments' items of try out, then it was seen the number of valid and invalid items of the test intrument. To analyze the level of the test items validity, the writers applied rtable (5\% and $1 \%$ ) to decide the valid or invalid of each test items. There were 40 valid and 10 invalid items of 50 items of the test instrument. Hence, 40 items were included in the pre- and posttest items and the 10 invalid items were mended and to include in the 50 items of the test intrument. Whereas, the measurement of the reliability of the instrument was undergone by implementing Product Moment Formula which resulted 0.97 from the try out. There were correlation between the odd items to even items of the total test items. Furthermore, to calculate the reliability of the test items, the writers employed Sperman Brown. It was yielded that the score of the reliability of the instrument is 0.99. So, the test items were eligible to apply in this research.

To collect the data, the writers administered pre- and post-tests to both sample groups. The pre-test was applied before both samples getting some treatments, whereas post-test was undergone after both samples getting some treatments. Based on the result of the distribution frequency of students' vocabulary achievement in pre-test at experimental group below: 


\begin{tabular}{|c|c|c|c|c|}
\hline $\begin{array}{c}\mathrm{N} \\
\mathrm{o}\end{array}$ & $\begin{array}{c}\text { Interv } \\
\text { al }\end{array}$ & $\begin{array}{c}\text { Frequen } \\
\text { cy }\end{array}$ & $\begin{array}{c}\text { Frequen } \\
\text { cy of } \\
\text { Absolute }\end{array}$ & $\begin{array}{c}\text { Frequency } \\
\text { of } \\
\text { Commulati } \\
\text { ve }\end{array}$ \\
\hline 1. & $25-30$ & 3 & $9 \%$ & 9 \\
\hline 2. & $31-36$ & 8 & $23 \%$ & 32 \\
\hline 3. & $37-42$ & 10 & $29 \%$ & 61 \\
\hline 4. & $43-48$ & 8 & $23 \%$ & 84 \\
\hline 5. & $49-54$ & 5 & $14 \%$ & 98 \\
\hline 6. & $55-60$ & 1 & $2 \%$ & 100 \\
\hline \multicolumn{2}{|c|}{ Total } & 35 & $100 \%$ & \\
\hline
\end{tabular}

\begin{tabular}{|l|l|l|l|l|}
\hline $\begin{array}{l}\mathrm{N} \\
\mathrm{o}\end{array}$ & $\begin{array}{l}\text { Interv } \\
\text { al }\end{array}$ & $\begin{array}{l}\text { Frequen } \\
\text { cy }\end{array}$ & $\begin{array}{l}\text { Frequen } \\
\text { cy of } \\
\text { Absolute }\end{array}$ & $\begin{array}{l}\text { Frequency } \\
\text { of } \\
\text { Commulati } \\
\text { ve }\end{array}$ \\
\hline 1. & $60-62$ & 5 & $14 \%$ & 14 \\
\hline 2. & $63-65$ & 7 & $20 \%$ & 34 \\
\hline 3. & $66-68$ & 18 & $51 \%$ & 85 \\
\hline 4. & $69-71$ & 4 & $12 \%$ & 97 \\
\hline 5. & $72-75$ & 1 & $3 \%$ & 100 \\
\hline \multicolumn{2}{|l|}{ Total } & 35 & $100 \%$ & \\
\hline
\end{tabular}

That the highest score of the experimental group is 60 in its frequency, $2 \%$ in its absolute frequency, and the lowest one is $25,9 \%$ of its absolute frequency. A mean of the data in experimental class is 40.7 and the standard deviation is 7.56.

The following table is the distribution frequency of students' vocabulary achievement in pre-test at Control group.

\begin{tabular}{|l|c|c|c|c|}
\hline $\begin{array}{c}\mathrm{N} \\
\mathrm{o}\end{array}$ & $\begin{array}{c}\text { Interv } \\
\text { al }\end{array}$ & $\begin{array}{c}\text { Frequen } \\
\text { cy }\end{array}$ & $\begin{array}{c}\text { Frequen } \\
\text { cy of } \\
\text { Absolute }\end{array}$ & $\begin{array}{c}\text { Frequency } \\
\text { of } \\
\text { Commulati } \\
\text { ve }\end{array}$ \\
\hline 1. & $20-26$ & 2 & $6 \%$ & 6 \\
\hline 2. & $27-33$ & 8 & $23 \%$ & 29 \\
\hline 3. & $34-40$ & 15 & $43 \%$ & 72 \\
\hline 4. & $41-47$ & 7 & $20 \%$ & 92 \\
\hline 5. & $48-54$ & 2 & $6 \%$ & 98 \\
\hline 6. & $55-61$ & 1 & $2 \%$ & 100 \\
\hline \multicolumn{2}{|c|}{ Total } & 35 & $100 \%$ & \\
\hline
\end{tabular}

The highest score owned by the control group is 60 , with $2 \%$ of its absolute frequency, and the lowest one is 20 , with $6 \%$ of its absolute frequency. A mean of the data in control group is 37.4 and the standard deviation is 7.47. We can see from the data above that most of the students' vocabulary are in low level.

The next steps in conducting this research were administering some treatments to both decided research samples. From the result of the first of two treatments applied to the experimental group as follows:

Based on that table above, the first treatment was undertaken to the experimental group showed that the highest score is in interval 72-75, it was in frequency of absolute $1 \%$ and the lowest one is in interval 60-62, it was in frequency of absolute 14\%. And most students got score in interval 66-68, it was in frequency of absolute $51 \%$. It is shown that the students' vocabulary mastery which were instructed by using snake ladders media were sligtly increased if it's compared to the result of its pre-test score. In line with that, from the result of the second treatment showed as follows:

\begin{tabular}{|l|l|l|l|l|}
\hline $\begin{array}{l}\mathrm{N} \\
\mathrm{o}\end{array}$ & $\begin{array}{l}\text { Interv } \\
\text { al }\end{array}$ & $\begin{array}{l}\text { Frequenc } \\
\mathrm{y}\end{array}$ & $\begin{array}{l}\text { Frequenc } \\
\text { y of } \\
\text { Absolute }\end{array}$ & $\begin{array}{l}\text { Frequency } \\
\text { of } \\
\text { Commulati } \\
\text { ve }\end{array}$ \\
\hline 1. & $60-62$ & 2 & $6 \%$ & 6 \\
\hline 2. & $63-65$ & 5 & $15 \%$ & 21 \\
\hline 3. & $66-68$ & 6 & $17 \%$ & 38 \\
\hline 4. & $69-71$ & 10 & $27 \%$ & 65 \\
\hline 5. & $72-74$ & 6 & $17 \%$ & 82 \\
\hline 6. & $75-77$ & 4 & $12 \%$ & 94 \\
\hline 7. & $78-80$ & 2 & $6 \%$ & 100 \\
\hline \multicolumn{2}{|l|}{ Total } & 35 & $100 \%$ & \\
\hline
\end{tabular}

In this second treatment showed that the highest score is in interval 78-80, it was in frequency of absolute $6 \%$ and the lowest one is interval 60-62, it was in frequency of absolute $6 \%$. And most students got score in interval 69-71, it was in frequency of absolute $27 \%$. It could be concluded that after the students got the second treatment, their vocabulary mastery were increased significantly. 
In the other hands, the writers also undertook two treatments to control class, each treatment consisted of one topic of a place description. The students were instructed by using scrabble media in each treatment to see the increasement of their vocabulary mastery. Based on the result of the first treatment was undergone to the control group below:

\begin{tabular}{|l|l|l|l|l|}
\hline $\begin{array}{l}\mathrm{N} \\
\mathrm{o}\end{array}$ & $\begin{array}{l}\text { Interv } \\
\text { al }\end{array}$ & $\begin{array}{l}\text { Frequen } \\
\text { cy }\end{array}$ & $\begin{array}{l}\text { Frequen } \\
\text { cy of } \\
\text { Absolute }\end{array}$ & $\begin{array}{l}\text { Frequency } \\
\text { of } \\
\text { Commulati } \\
\text { ve }\end{array}$ \\
\hline 1. & $50-52$ & 3 & $9 \%$ & 9 \\
\hline 2. & $53-55$ & 4 & $11 \%$ & 20 \\
\hline 3. & $56-58$ & 7 & $20 \%$ & 40 \\
\hline 4. & $59-61$ & 13 & $37 \%$ & 77 \\
\hline 5. & $62-64$ & 5 & $14 \%$ & 91 \\
\hline 6. & $65-67$ & 2 & $6 \%$ & 97 \\
\hline 7. & $68-70$ & 1 & $3 \%$ & 100 \\
\hline \multicolumn{2}{|l}{ Total } & 35 & $100 \%$ & \\
\hline
\end{tabular}

Based on the table above that the distribution frequency of the control group in the first treatment showed that the highest score is in interval 68-70, it was in frequency of absolute $1 \%$ and the lowest one is in interval 50-52, it was in frequency of absolute 3\%. And most students got score in interval 59-61, it was in frequency of absolute $37 \%$. It could be identified that the control group students were insufficient in mastering vocabulary.

Furthermore, the writers conducted the second treatment to the control group. It yielded 80 for the highest score and 60 for the lowest score. The detailed explanation can be seen below:

\begin{tabular}{|l|l|l|l|l|}
\hline $\begin{array}{l}\mathrm{N} \\
\text { o }\end{array}$ & $\begin{array}{l}\text { Interv } \\
\text { al }\end{array}$ & $\begin{array}{l}\text { Frequen } \\
\text { cy }\end{array}$ & $\begin{array}{l}\text { Frequen } \\
\text { cy of } \\
\text { Absolute }\end{array}$ & $\begin{array}{l}\text { Frequency } \\
\text { of } \\
\text { Commulati } \\
\text { ve }\end{array}$ \\
\hline 1. & $60-62$ & 3 & $9 \%$ & 9 \\
\hline 2. & $63-65$ & 4 & $11 \%$ & 20 \\
\hline 3. & $66-68$ & 5 & $14 \%$ & 34 \\
\hline 4. & $69-71$ & 14 & $40 \%$ & 74 \\
\hline 5. & $72-74$ & 4 & $11 \%$ & 85 \\
\hline 6. & $75-77$ & 3 & $9 \%$ & 94 \\
\hline 7. & $78-80$ & 2 & $6 \%$ & 100 \\
\hline \multicolumn{2}{|l|}{ Total } & 35 & $100 \%$ & \\
\hline
\end{tabular}

After the writers applied scrabble media in the first meeting, the writers continued to give second treatment to the control group. By analyzing the result of the treatment, it is shown that the highest score is in interval $78-80$, it was in frequency of absolute $6 \%$ and the lowest one is in interval 60-62, it was in frequency of absolute $6 \%$. And most students got score in interval 69-71, it was in frequency of absolute $40 \%$. It could be concluded that after the students got the second treatment, their vocabulary mastery became increased significantly.

When the writers accomplished to give two treatments to both samples, the writers administered post-tests to both samples to find out some feedback after applying both learning media on their learning process. The post-test was employed to figure out the students' vocabulary mastery after they received some treatments. The post-tests were administered to experimental and control groups to see the significant different result between applying snake ladders to scrabble media toward students' vocabulary mastery.

The following table describe the distribution frequency of students' vocabulary achievement in post-test at Experimental group, as follows:

\begin{tabular}{|l|l|l|l|l|}
\hline $\begin{array}{l}\mathrm{N} \\
\text { o }\end{array}$ & $\begin{array}{l}\text { Interv } \\
\text { al }\end{array}$ & $\begin{array}{l}\text { Frequen } \\
\text { cy }\end{array}$ & $\begin{array}{l}\text { Frequen } \\
\text { cy of } \\
\text { Absolute }\end{array}$ & $\begin{array}{l}\text { Frequency } \\
\text { of } \\
\text { Commulati } \\
\text { ve }\end{array}$ \\
\hline 1. & $50-55$ & 2 & $6 \%$ & 6 \\
\hline 2. & $56-61$ & 5 & $14 \%$ & 20 \\
\hline 3. & $62-67$ & 4 & $11 \%$ & 31 \\
\hline 4. & $68-73$ & 13 & $37 \%$ & 68 \\
\hline 5. & $74-79$ & 8 & $23 \%$ & 91 \\
\hline 6. & $80-85$ & 3 & $9 \%$ & 100 \\
\hline \multicolumn{2}{|l|}{ Total } & 35 & $100 \%$ & \\
\hline
\end{tabular}

Based on that chart that the experimental class resulted 85 for the highest score which was in frequency of absolute $9 \%$ and 50 for the lowest one which was in frequency of absolute $6 \%$. 
And it had a mean of 69.5 and standard deviation of 7.91 .

The following table elaborates the control group distribution frequency of students' vocabulary achievement in posttest, as follows:

\begin{tabular}{|c|c|c|c|c|}
\hline $\begin{array}{c}\mathrm{N} \\
\mathrm{o}\end{array}$ & $\begin{array}{c}\text { Interv } \\
\text { al }\end{array}$ & $\begin{array}{c}\text { Frequen } \\
\text { cy }\end{array}$ & $\begin{array}{c}\text { Frequen } \\
\text { cy of } \\
\text { Absolute }\end{array}$ & $\begin{array}{c}\text { Frequency } \\
\text { of } \\
\text { Commulati } \\
\text { ve }\end{array}$ \\
\hline 1. & $40-46$ & 1 & $3 \%$ & 3 \\
\hline 2. & $47-53$ & 3 & $6 \%$ & 9 \\
\hline 3. & $54-60$ & 5 & $14 \%$ & 23 \\
\hline 4. & $61-67$ & 16 & $48 \%$ & 71 \\
\hline 5. & $68-74$ & 8 & $23 \%$ & 94 \\
\hline 6. & $75-81$ & 2 & $6 \%$ & 100 \\
\hline \multicolumn{2}{|c|}{ Total } & 35 & $100 \%$ & \\
\hline
\end{tabular}

Meanwhile, the control group yielded 80 for the highes score which was in frequency of absolute $6 \%$ and 40 for the lowest score which was in frequency of absolute $3 \%$. And it had a mean of $63.6 \%$ and its standard deviation is 7.66.

After delivering the tests to both samples, the writers employed normality test formula to determine whether the test data is in normal distribution or not. The normality data accepted Ho if X2 count $\leq$ $X 2$ list for the significant level 5\% $(\alpha=$ $0.05)$ and also the significant level $1 \%(\alpha$ $=0.01$ ).

\begin{tabular}{|c|c|c|c|c|c|}
\hline \multirow[b]{3}{*}{ Test } & \multirow[b]{3}{*}{$\begin{array}{c}\text { Variabl } \\
\text { e }(\mathrm{X})\end{array}$} & \multirow{3}{*}{$\begin{array}{c}X^{2} \\
\text { coun } \\
t\end{array}$} & & & \multirow[b]{3}{*}{$\begin{array}{c}\text { Conclusi } \\
\text { on }\end{array}$} \\
\hline & & & \multicolumn{2}{|c|}{$\begin{array}{c}\text { Significant } \\
\text { Level }\end{array}$} & \\
\hline & & & $\begin{array}{c}5 \% \\
(\alpha= \\
0.05 \\
)\end{array}$ & $\begin{array}{c}1 \% \\
(\alpha= \\
0.01 \\
)\end{array}$ & \\
\hline \multirow{2}{*}{$\begin{array}{l}\text { Pre- } \\
\text { test }\end{array}$} & $\mathrm{XB}$ & 0.58 & 7.81 & 11.3 & Normal \\
\hline & $\mathrm{XF}$ & 2.20 & 7.81 & 11.3 & Normal \\
\hline \multirow{2}{*}{$\begin{array}{l}\text { Post } \\
\text {-test }\end{array}$} & $\mathrm{XB}$ & 4.66 & 7.81 & 11.3 & Normal \\
\hline & $\mathrm{XF}$ & 3.63 & 7.81 & 11.3 & Normal \\
\hline
\end{tabular}

Based on the table above, it is obtained that $X^{2}$ count, pre-test and posttest data are lowest than $X^{2}$ list in the significance level of 5\% $(\alpha=0.05)$ and also $1 \%(\alpha=0.01)$. So, it means that the both samples which came from the population are in normal distribution.

Meanwhile, from the result of homogeneity test showed that both samples have equal variance. The data of the homogeneity test rejected when the significant level $10 \%(\alpha=0.05)$ and also the significant level $2 \%(\alpha=0.01)$.

\begin{tabular}{|c|c|c|c|c|}
\hline \multirow{2}{*}{ Test } & \multirow{2}{*}{$\begin{array}{c}\mathrm{F} \\
\text { count }\end{array}$} & \multicolumn{2}{|c|}{$\begin{array}{c}\text { Significant } \\
\text { Level }\end{array}$} & \multirow{2}{*}{ Conclusion } \\
\cline { 3 - 4 } & & $\begin{array}{c}10 \% \\
(\alpha= \\
0.05)\end{array}$ & $\begin{array}{c}2 \%(\alpha \\
= \\
0.01)\end{array}$ & \\
\hline $\begin{array}{c}\text { Pre- } \\
\text { test }\end{array}$ & 1.02 & 1.80 & 2.30 & Homogenous \\
\hline $\begin{array}{c}\text { Post- } \\
\text { test }\end{array}$ & 1.07 & 1.80 & 2.30 & Homogenous \\
\hline
\end{tabular}

From the table above, it is obtained that $\mathrm{f}$ hit of pre and post tess have the lowest level than $\mathrm{f}$ list ( $\mathrm{f}$ count $<\mathrm{f}$ list) in the significant level of $10 \%(\alpha=0.05)$ and $2 \%$ $(\alpha=0.01)$. It means that both samples come from the populations whose the same or equal variance.

Finally, after analyzing the data, the writers found out that there is a difference of using snake ladders media to scrabble media toward students' vocabulary mastery, and it was concluded that snake ladders media is more effective than scrabble media toward students' vocabulary mastery.

\section{Conclusion}

Based on the analyzing data above, the writers conclude that there is different result toward students' vocabulary mastery by using snake ladders to scrabble media. Snake ladders media is proved effective in increasing the students' vocabulary mastery.

\section{Suggestions}

Since snake ladders media is proved effective in increasing the students' vocabulary mastery. So, the English teacher may implement this media to 
teach vocabulary to his students in the class. The implementation of the media consist of some steps. They are, the snake ladders, dice and a glass should be provided, then, the students are grouped into four, then, the group who on the first start should shake the dice and throw it out. Then, it determines how many steps do they get, then the players have to translate and pronounce some words written in the stop space they have. Finally, the player will continue her or his step if the answer is correct. Nevertheless, if the answer is incorrect, she or he has to step three space back. The winner is the player who can step the finish space fast.

The teacher must also anticipate the weakness of snake ladders media, namely it can not be effectively used in a big class. Since the teacher should provide more snake ladders board, dice, glasses to the students. Then, the teacher should give more supervision to all groups in the class at the same time.

\section{Reences}

Anonymous. (2011). How to play snakes \& Ladders. Retrieved from http://www.ehow.com/how_20827 35 play-snakesladders.html.

Arikunto, Suharsimi. (2010). Prosedur penelitian suatu pendekatan praktek.Jakarta: PT. Bina Aksara

Barnhart, Cynthia A. (2008). The facts on file student's dictionary of American English.

Retrieved from http://id.shyoong.com /social sciences/education /2249726/\#ixzz2SvnROP2r

Furchan, Arief. (1982). Pengantar penelitian dalam pendidikan. Surabaya: Usaha Nasional.

Gay, L, R. (1990). 'Is this collaboration?' Collaborative learning: underlying process and effective techniques. New directions for teaching and learning No. 59. Bosworth: Hamilton, S,J. (Eds.)
Hastutik. (2009). Effectiveness of scrabble game in increasing vocabulary mastery in the first year class of SMP Darul Mutta'allimin Sidoarjo.Sidoarjo: SMP Darul Mutta'allimin Sidoarjo

Hornby, A S. (1995). Oxford advanced learner's dictionary of current English. Great Britain : Oxford University Press.

Huyen, Nguyen T. (2003). Learning vocabulary through games. Vietnam: Asian EFL.

Penny Ur. (1991). A course in language teaching: practice and theory. Cambridge University Press.

Cruickshank, D. R., \& Telfer, R. (2001). Classroom games and simulations. Theory into practice. Winter 80, 19(1), 75-81

Sadiman, Arif. (2009). Media pendidikan, pengertian, pengembangan dan pemanfaatannya. Jakarta: Raja Grafindo Persada.

Suganda, et al. (2008) Increasing the students' speaking ability in English through snake ladders game in class VII-A 1 Cimahi. Cimahi: SMP Negeri 1 Cimahi.

Sugiyono. (2012). Metode penelitian kuantitatif kualitatif dan $R \& D$. Bandung: Aylfa Beta

Thornbury, Scott. (2002). How to teach vocabulary. The United State : Pearson Education Limited. 